\title{
Range distribution and contributions to taxonomy of Elops smithi (ELOPIFORMES: ELOPIDAE)
}

\author{
RODRIGO P.C. DE SOUSA ${ }^{1}$, DENISE SODRÉ ${ }^{4}$, RAUQUÍRIO M. DA COSTA ${ }^{4}$, \\ MARCELO VALLINOTO ${ }^{1,3}$, EDIVALDO H.C. OLIVEIRA ${ }^{5}$, GLÁUCIA C. SILVA- \\ OLIVEIRA $^{1}$, IRACILDA SAMPAIO ${ }^{2}$ and AURYCÉIA GUIMARÃES-COSTA ${ }^{2}$
}

\author{
${ }^{1}$ Universidade Federal do Pará, Laboratório de Evolução, Alameda Leandro Ribeiro, s/n, Aldeia, 68600-000 Bragança, PA, Brazil \\ ${ }^{2}$ Universidade Federal do Pará, Laboratório de Genética e Biologia Molecular, \\ Alameda Leandro Ribeiro, s/n, Aldeia, 68600-000 Bragança, PA, Brazil \\ ${ }^{3} \mathrm{CIBIO} / \mathrm{InBIO}$, Centro de Investigacão em Biodiversidade e Recursos Genéticos, \\ Universidade do Porto, 4485-661, Vairão, Portugal \\ ${ }^{4}$ Universidade Federal do Pará, Laboratório de Plâncton e Cultivo de Microalgas. \\ Alameda Leandro Ribeiro, s/n, Aldeia, 68600-000 Bragança, PA, Brazil \\ ${ }^{5}$ Instituto Evandro Chagas, Laboratório de Cultura de Tecidos e Citogenética Animal, \\ Rodovia BR-316 Km 7, s/n, Levilândia, 67030-000 Ananindeua, PA, Brazil
}

Manuscript received on November 28, 2018; accepted for publication on August 29, 2019

\begin{abstract}
How to cite: SOUSA RPC, SODRÉ D, COSTA RM, VALLINOTO M, OLIVEIRA EHC, SILVA-OLIVEIRA GC, SAMPAIO I AND GUIMARÃES-COSTA A. 2019. Range distribution and contributions to taxonomy of Elops smithi (ELOPIFORMES: ELOPIDAE). An Acad Bras Cienc 91: e20181240. DOI 10.1590/0001-3765201920181240.
\end{abstract}

\begin{abstract}
This study presents the first record of Elops smithi for northern Brazil. The evidence suggests this species is being misidentified incorrectly as Elops saurus in estuaries of the Western Atlantic Ocean. Here, morphological, molecular, and cytogenetic evidence identified all ladyfish specimens from one estuary in the region as E. smithi. Thus, at least Elops smithi occurs in the northern coast of Brazil and it is recommended that specimens from this region identified as E. saurus be further investigated with genetic and cytogenetic tools in order to assure a correct species identification.
\end{abstract}

Key words: Elopidae, Karyotype, Ladyfish, Malacho, Mitochondrial DNA.

\section{INTRODUCTION}

The family Elopidae includes only the genus Elops, with seven species distributed throughout the tropics. Until recently, the ladyfish, Elops saurus, was the only elopid species known to occur in the northwestern Atlantic (Obermiller and Pfeiler 2003, McBride et al. 2010). However, Smith (1989) identified the presence of two sympatric

Correspondence to: Marcelo Vallinoto

E-mail: mvallino@ufpa.br

ORCID: https://orcid.org/0000-0002-3465-3830 larval morphs within this area, distinguished by the number of myomeres. Based on the analysis of mitochondrial Cytb sequences and morphological data, McBride et al. (2010) confirmed that the morph with the lower myomere count was, in fact, a distinct species, which they denominated Elops smithi. The divergence of the Cytb haplotypes of $E$. saurus and E. smithi ranged from $2.3 \%$ to $2.9 \%$ (McBride et al. 2010).

Elops saurus is distributed throughout the northwestern Atlantic, including the Gulf of Mexico and the Yucatan Peninsula, and was 
originally considered to inhabit only the Northern Hemisphere, while E. smithi occurs in the central Atlantic, Bahamas, and the Caribbean Sea, and is sympatric with E. saurus on the southeastern coast of the United States and in the Gulf of Mexico (McBride and Horodysky 2004, McBride et al. 2010).

In the southwestern Atlantic, E. smithi has been recorded in marine, coastal, and estuarine environments (Lucena and Carvalho-Neto 2012, Machado et al. 2012, Sánchez-Botero et al. 2016). In most surveys of fish populations on the Brazilian coast, however, E. saurus has been identified as the most common elopid species (Franco et al. 2014, Garcia-Junior et al. 2015, Pinheiro et al. 2015, Marceniuk et al. 2017, Medeiros et al. 2018, Mendes et al. 2018).

In studies of fish, a cytogenetic approach has become an increasingly effective tool for the identification of cryptic species (Harrison et al. 2007, Martinez et al. 2016), the elucidation of the origin of hybrids (Majtánová et al. 2016, Pereira et al. 2014), and the interpretation of phylogenetic relationships (Majtánová et al. 2017, Ramirez et al. 2017), as well as the understanding of chromosome structure (Jacobina et al. 2011). Until now, the only cytogenetic data available for the family Elopidae refer to the diploid number of E. saurus (Doucette and Fitzsimons 1982). The present study provides the first records of E. smithi from the region of the Brazilian Amazon estuary and discusses the relative effectiveness of morphological-meristic, molecular, and cytogenetic data approaches for the identification of the species.

\section{MATERIALS AND METHODS}

\section{COLLECTION OF Elops smithi SPECIMENS}

Larval, juvenile, and adult Elops specimens were collected for this study. The larvae were collected from the subsurface layer $(\approx 0.5 \mathrm{~m}$ depth) of the water column in the Taperaçu estuary in northern
Brazil (4645’25.2” W, 056’47.1” S; Fig. 1, zone 1) with horizontal plankton trawls with conical nets with mesh of $300 \mu \mathrm{m}$ and $500 \mu \mathrm{m}$. Once collected, some $E$. smithi larvae were immediately stored in $70 \%$ alcohol for molecular analyses, while others were stored in $4 \%$ formaldehyde for meristic analyses. The larvae were identified based on the literature (Bonecker and Castro 2006, McBride et al. 2010), and described following the general criteria and terminology proposed by Gehringer (1959).

Ten juveniles were collected from a saline lagoon located in a tract of mangrove near the Taperaçu estuary $\left(46^{\circ} 40^{\prime} 5.71\right.$ ' W, $0^{\circ} 53$ '53.22" $\mathrm{S}$; Fig. 1, zone 2) using a fishing net with a 25 $\mathrm{mm}$ mesh. The adult specimen was captured on the adjacent continental shelf $\left(46^{\circ} 35^{\prime} 24.0^{\prime}\right.$ ' W, $0^{\circ} 49^{\prime} 32.0^{\prime \prime}$ S; Fig. 1, zone 3) using the same net. All specimens were deposited in the ichthyological collection of the Ichthyology Laboratory of the Aquatic Ecology Group at the Federal University of Pará in Belém (GEA.ICT).

\section{DNA EXTRACTION, PCR, AND SEQUENCING}

To confirm the identification of the species, DNA was extracted from the specimens based on the standard protocol for the DNA Wizard Genomic Purification kit (Promega Corporation, Madison, WI - USA). A fragment of the mitochondrial Cytochrome $b(C y t b)$ gene was amplified by PCR, using the primers Cyb-09H (Song et al. 1998) and Cyb-07L (Taberlet et al. 1992), using the protocol described by McBride et al. (2010). The amplified products were purified using the ExoSAP-IT enzyme and sequenced in an ABI 3500 automatic sequencer (Applied Biosystems) using a BigDye Terminator Cycle Sequencing kit (Applied Biosystems).

\section{MOLECULAR ANALYSES}

The $C y t b$ sequences were amplified to investigate the genetic differences and similarities between 


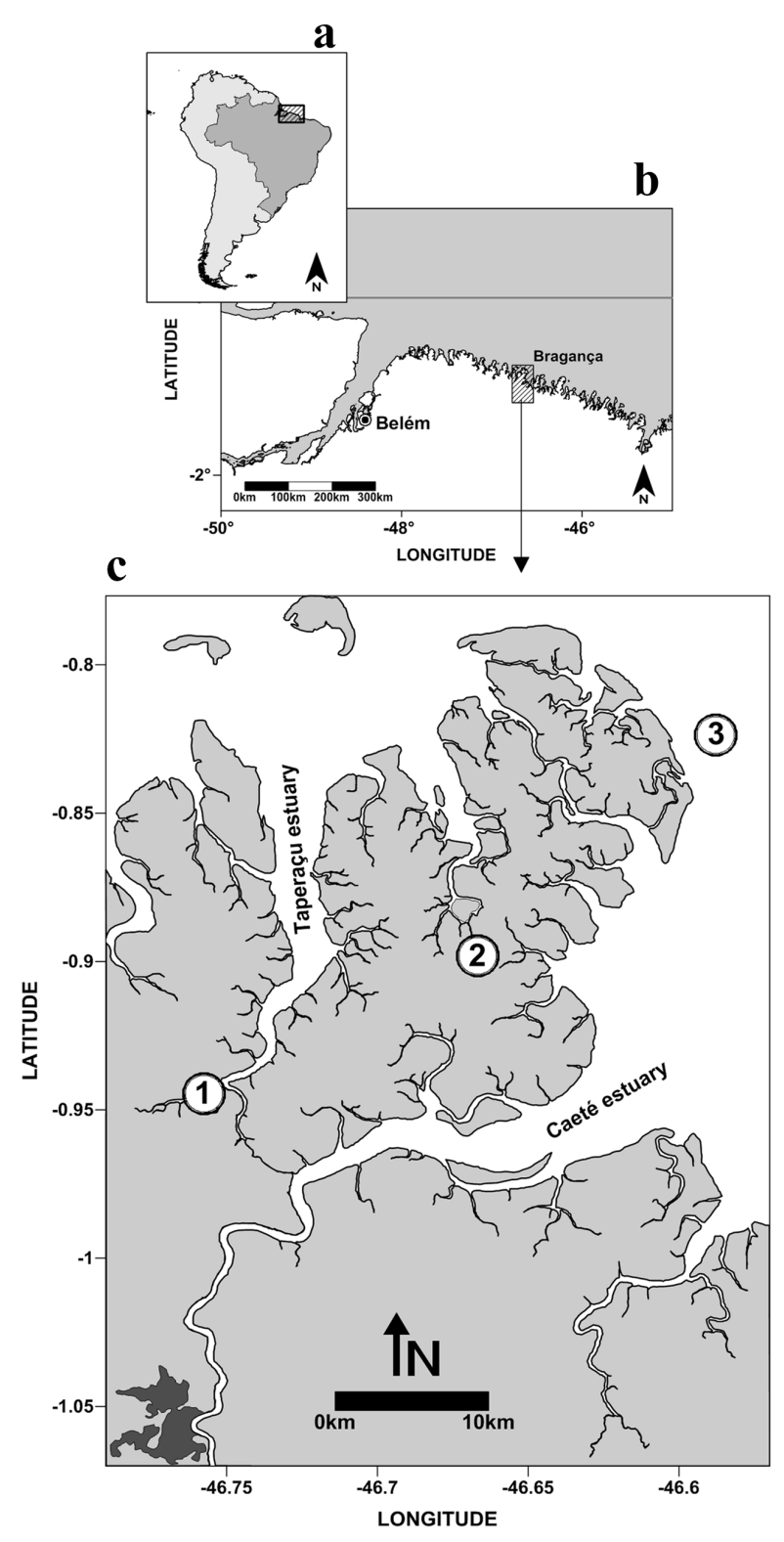

Figure 1 - Study area: South America (a), Northern Brazil coast (b), and positions of the sampling stations in Pará coastal zone - 1, Taperaçu estuary; 2, salt lagoon; 3, continental shelf (c).

our specimens and the elopid species found in the southwestern Atlantic (E. saurus and E. smithi) and eastern Pacific (Elops affinis). The osteoglossid Osteoglossum bicirhosum (Vandelli 1829) was used as the outgroup. Genetic divergence was determined based on the Kimura 2-parameter statistic (K2P), and a neighbor-joining distance tree (bootstrap with 1,000 pseudo-replicates) of the Elops species was constructed in MEGA version 7 (Kumar et al. 2016).

\section{CYTOGENETIC ANALYSES}

Fragments of fin were removed from the specimens in the laboratory. Cell culture followed the protocol of Sasaki et al. (1968), and mitotic chromosomes were obtained from a fixed and hypotonized cell suspension by the air-drying procedure (Bertollo et al. 1978). The chromosomes were NOR-banded to reveal the active nucleolus organizer regions, following the procedure developed by Howell and Black (1980). The banded metaphases were visualized and photographed under a LEICA 1000 DM microscope, in a light field with an immersion lens. The karyotype of the species was assembled using GENASIS version 7.2.6.19509.

\section{MORPHOLOGICAL ANALYSES}

The reliability of the diagnostic characteristics described in previous studies was assessed by comparing the morphological-meristic traits (standard length [SL], number of dorsal, anal, and pectoral rays, total number of myomeres, and number of pre-anal myomeres) of the Elops specimens collected in the present study with the parameters described in the literature.

\section{RESULTS}

MORPHOLOGICAL AND MOLECULAR IDENTIFICATION OF THE Elops smithi LARVAE

A total of 59 E. smithi larvae were identified in the plankton samples collected from the Taperaçu estuary. The shortest standard length of a larva was $22.99 \mathrm{~mm}$, and the longest, $34.95 \mathrm{~mm}$, with a mean of $29.27 \pm 4.81 \mathrm{~mm}$. The most effective morphological character for the identification of E. smithi was the pre-anal myomere count. The larvae collected in the Taperaçu estuary had 61-67 pre-anal myomeres. 
The larvae represented two development stages, the leptocephalus $(64.40 \%$ of the larvae) and pre-metamorphic (35.60\%) stages. The juveniles and the only adult specimen presented 21-22 dorsal fin rays, 14 anal fin rays and 13-14 pectoral fin rays.

In the present study the E. smithi larvae were captured in a saline estuary, which is consistent with the data on the larval ecology of E. saurus. The juveniles (SL: 175-180 mm) were also collected in a coastal saline lagoon near the Taperaçu estuary. The adult specimen (SL: $470 \mathrm{~mm}$ ) was collected at sea, $41.8 \mathrm{Km}$ off the coast of Pará.

Comparisons of the Cytb sequences with those of the Elops species available in GenBank indicated that all the specimens collected on the coast of Pará belonged to the species E. smithi (Fig. 2A). This diagnosis was further reinforced by the mean genetic distance of $0.8 \%$ within the group that includes the specimens collected during the present study and E. smithi from other areas in the coastal western Atlantic (Table I).

\section{CYTOGENETIC ANALYSES}

Fifty metaphases were analyzed to describe the diploid number, and 30 were used to describe the NOR banding. The diploid number of E. smithi was $2 \mathrm{n}=50(6 \mathrm{M}+4 \mathrm{ST}+42 \mathrm{~A})$, with a fundamental number (FN) of 60 (Fig. 2b). The NORs were observed in the centromere of pair 14, presenting different sizes for the banding signals.

\section{DISCUSSION}

The present study is the first to record E. smithi (larvae, juveniles and adult specimens) on the Amazon coast of northern Brazil (Fig.1). The majority of the E. smithi larvae analyzed here had 61-67 pre-anal myomeres, which is comparable with the counts recorded for E. smithi in Uruguay (Lucena and Carvalho-Neto 2012) and southern Brazil (Machado et al. 2012). The genetic distances
TABLE I

Summary of the pairwise sequence divergence (K2P percentage), based on Cytb gene, between Elops species.

\begin{tabular}{cccccc}
\hline \multicolumn{1}{c}{} & $\mathbf{1}$ & $\mathbf{2}$ & $\mathbf{3}$ & $\mathbf{4}$ \\
\hline 1 & Elops smithi_this study & & & & \\
2 & Elops sp. & 0.008 & & & \\
3 & Elops saurus & 0.019 & 0.021 & & \\
4 & Elops affinis & 0.029 & 0.028 & 0.032 & \\
\hline
\end{tabular}

recorded in the Cytb sequences (1.9-2.9\%) also distinguished E. smithi unequivocally from $E$. saurus.

The leptocephali and pre-metamorphic $E$. smithi larvae were collected in the innermost portion of the Taperaçu estuary, reinforcing the conclusion that this species is estuarine-dependent, as suggested by Ray (1997) and McBride et al. (2001). The life stages of Elops species are welldefined, with the adults and early larval stages being found on the continental shelf, while spawning occurs in coastal waters and the later larval and juvenile stages are found in estuaries (Gehringer 1959, Eldred and Lyons 1966, Adams et al. 2014).

The karyotype of E. smithi, described here for the first time, is clearly different from that of $E$. saurus $-2 \mathrm{n}=48(6 \mathrm{M} / \mathrm{ST}+42 \mathrm{ST} / \mathrm{A}, \mathrm{FN}=54)-$ which was described by Doucette and Fitzsimons (1982). In E. smithi, not only is the diploid number different, but the whole arrangement is quite distinct $-2 \mathrm{n}=50(6 \mathrm{M}+4 \mathrm{ST}+40 \mathrm{~A}, \mathrm{NF}=60)$. These differences provide diagnostic markers for the distinction of the two species, reinforcing the conclusions of Harrison et al. (2007) and Sczepanski et al. (2010) on the importance of these markers for the description of new species of fish.

The E. smithi karyotype has a larger number of two-armed chromosomes than that of E. saurus. As the basal karyotype of marine teleosts is assumed to be $2 \mathrm{n}=48$ single-armed chromosomes (Vitturi et al. 1995, Nirchio et al. 2004), fusions and chromosomal rearrangements may have played an 
a)
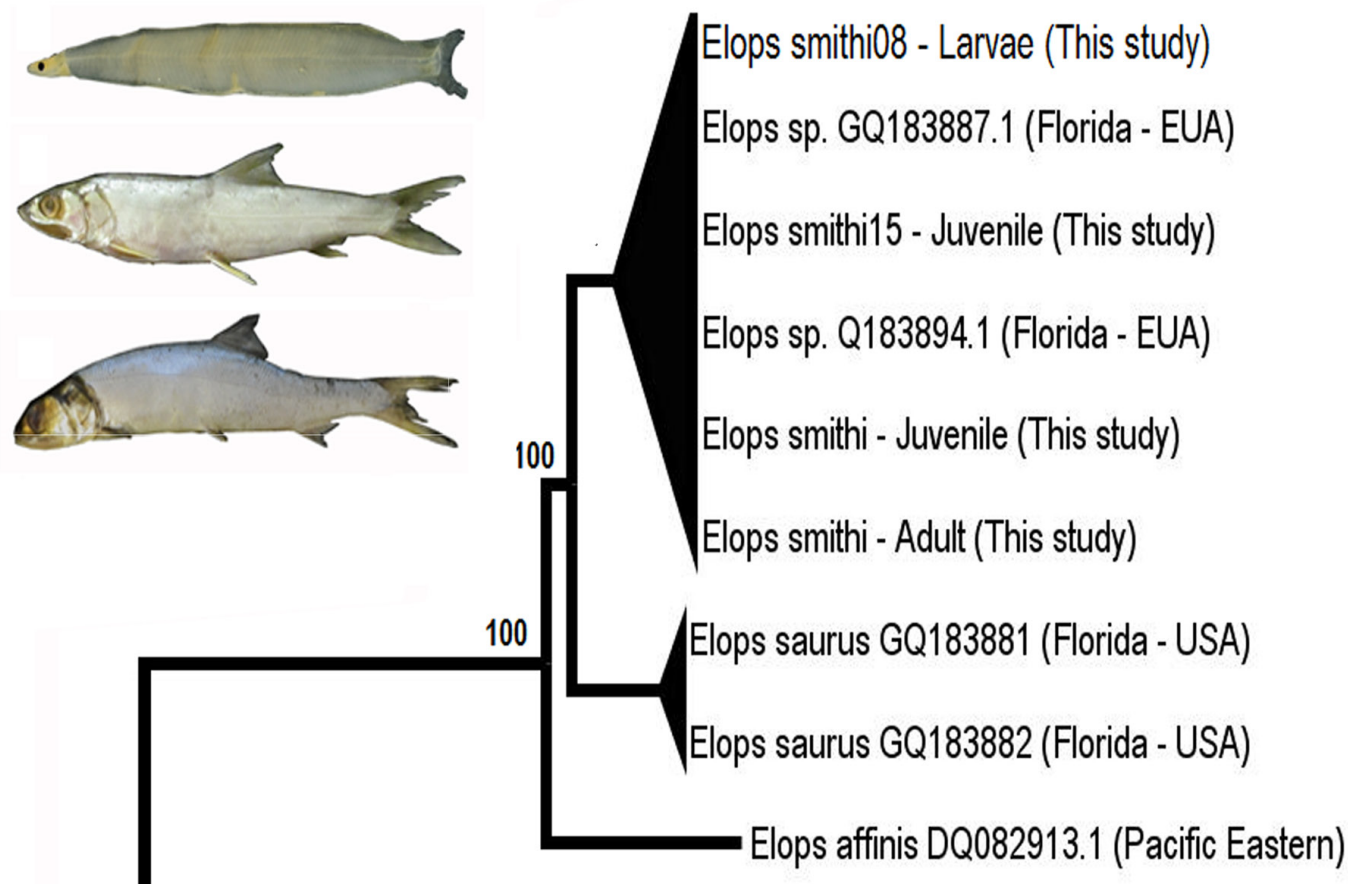

Osteoglossum bicirrhosum $\mathrm{AB} 035238.1$

b)
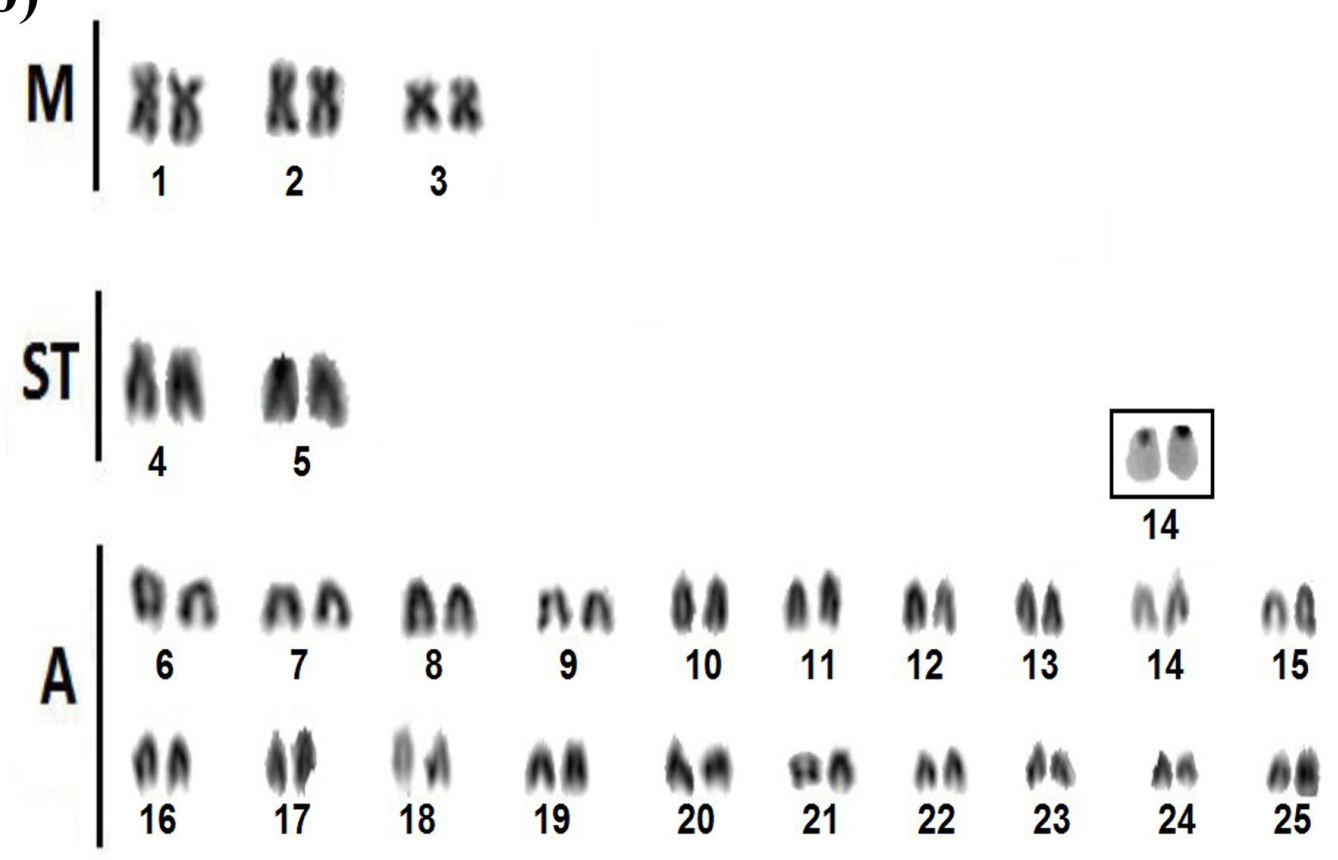

Figure 2 - a) Distance tree (neighbour-joining) with Elops species: pre-metamorphic larvae (33.31 mm SL), juvenile individual (175 mm SL), and adult individual $(410 \mathrm{~mm} \mathrm{SL})$. The numbers at the branches are the bootstrap support values for K2P; b) Karyotype of Elops smithi stained conventionally with Giemsa and the nucleolar organizer region (NOR) bearing pair (14) after silver nitrate staining. 
important role in the chromosomal evolution of the Elopiformes (Merlo et al. 2005).

This is the first description of NOR banding in an Elops species, datas of NOR has providing important insights to taxonomy of some groups of fish (Benzaquem et al. 2008). In vertebrates, NORs are associated predominantly with the telomeric and interstitial regions of the chromosome, but in $E$. smithi, these markers were found in the centromeric region, a pattern rarely observed in fish, which has been interpreted as the result of paracentric inversions or translocations (Bittencourt et al. 2014). Variations in the size of the NORs in fishes are associated primarily with structural changes, such as duplications and deletions (Cross et al. 2006, Fujiwara et al. 2007). Such events may have occurred during karyotypical evolution of E. smithi.

The findings of this study indicate clearly that the morphological similarities of E. saurus and $E$. smithi may have led to the frequent misidentification of the specimens collected in past surveys. Given this, existing specimens from the northern Brazilian coast identified as E. saurus require new genetic or cytogenetic confirmation, given that sympatry of these two species on the western coast of the South Atlantic is yet to be confirmed.

\section{ACKNOWLEDGMENTS}

This study was financed by Coordenação de Aperfeiçoamento de Pessoal de Nível Superior (CAPES), the Evandro Chagas Institute (IEC) and Conselho Nacional de Desenvolvimento Científico e Tecnológico (CNPq). MV is supported by a CNPq fellowship (302 892/2016-8).

\section{AUTHOR CONTRIBUTIONS}

RPCS and AGC wrote the manuscript and performed cytogenetic and molecular analysis; RPCS, DS and RMC collected samples and performed morphological identification; EHCO and GCSO provide the structural and technical support for cytogenetic analysis; MV and IS assisted in molecular analysis and provided financial support. All authors edited in approved the manuscript.

\section{REFERENCES}

ADAMS AJ, HORODYSKY AZ, MCBRIDE RS, GUINDON K, SHENKER J, MACDONALD TC, HARWELL HD, WARD R AND CARPENTER K. 2014. Global conservation status and research needs for tarpons (Megalopidae), ladyfishes (Elopidae) and bonefishes (Albulidae). Fish Fisher 15: 280-311.

BENZAQUEM DC, FELDBERG F, PORTO, JIR, GROSS MC AND ZUANON JAS. 2008. Cytotaxonomy and karyoevolution of the genus Crenicichla (Perciformes, Cichlidae). Compar Cytogen 31: 250-255.

BERTOLLO LAC, TAKAHASHI CS AND MOREIRAFILHO O. 1978. Cytotaxonomic considerations on Hoplias lacerdae (Pisces, Erythrinidae). Braz J Genetic 1: 103-120.

BITENCOURT JA, SAMPAIO I, RAMOS RBT AND AFFONSO PRAM. 2014. Chromosomal fusion in Brazilian populations of Trinectes inscriptus Gosse, 1851 (Pleuronectiformes; Achiridae) as revealed by internal telomere sequences (ITS). J Exp Marine Biol Ecol 452: 101-104.

BONECKER ACT AND CASTRO MS. 2006. Atlas de Larvas de Peixes da Região Central da Zona Econômica Exclusiva Brasileira, $1^{\text {a }}$ ed., Rio de Janeiro, RJ: Séries Livros.

CROSS I, MERLO A, MANCHADO IM, CANÃVATE CJP AND REBORDINOS L. 2006. Cytogenetic characterization of the sole Solea senegalensis (Teleostei: Pleuronectiformes: Soleidae): Ag-NOR, (GATA)n, (TTAGGG)n and ribosomal genes by one-color and twocolor FISH. Genetica 12: 253-259.

DOUCETTE AJ AND FITZSIMONS JM. 1982. Karyology of the ladyfishes Elops saurus. Jap J Ichthyol 29: 223-226.

ELDRED B AND LYONS W. 1966. Larval ladyfish, Elops saurus Linnaeus 1766, (Elopidae) in Florida and adjacent waters. Florida Department of Natural Resources, Marine Research Laboratory: Leaflet Series.

FRANCO TP, ARAÚJO CEO AND ARAÚJO FG. 2014 Length-weight relationships for 25 fish species from three coastal lagoons in Southeastern Brazil. J Appl Ichthyol 30: 248-250.

FUJIWARA A, FUJIWARA M, NISHIDA-UMEHARA C, ABE S AND MASAOKA T. 2007. Characterization of Japanese flounder karyotype by chromosome bandings and fluorescence in situ hybridization with DNA markers. Genetica 131: 267-274.

GARCIA - JÚNIOR J, NÓBREGA MF AND OLIVEIRA JEL. 2015. Coastal fishes of Rio Grande do Norte, northeastern Brazil, with new records. Check List 11: 1-24. 
GEHRINGER JW. 1959. Early development and metamorphosis of the tenpounder Elops saurus Linnaeus. Fish Bullet 59: 618-647.

HARRISON IJ, NIRCHIO M, OLIVEIRA C, RON E AND GAVIRIA J. 2007. A new species of mullet (Teleostei: Mugilidae) from Venezuela, with a discussion on the taxonomy of Mugil gaimardianus. J Fish Biol 71: 76-97.

HOWELL WM AND BLACK DA. 1980. Controlled silver staining of nucleolus organizer regions with a protective colloidal developer: a 1-step method. Experientia 36: 1014-1015.

JACOBINA UP, CIOFFI MB, SOUZA LGR, CALADO LL, TAVARES M, MANZELLA J, BERTOLLO LAC AND MOLINA WF. 2011. Chromosome mapping of repetitive sequences in Rachycentron canadum (Perciformes: Rachycentridae): implications for karyotypic evolution and perspectives for biotechnological uses. J Biomed Biotechnol 2011: 1-8.

KUMAR S, STECHER G AND TAMURA K. 2016. MEGA7: molecular evolutionary genetics analysis version 7.0 for bigger datasets. Mol Biol Evol 33: 1870-1874.

LUCENA CAS AND CARVALHO-NETO P. 2012. Elopomorpha leptocephali from Southern Brazil: a new report of Albula sp. (Albulidae) and first record of Elops smithi (Elopidae) in Brazilian waters. Biotemas 25: 297301.

MACHADO I, VERA M, CALLIARI D AND RODRÍGUEZGRAÑA L. 2012. First record of an Elops smithi (Pisces: Elopidae) larva in a South American subtropical temperate estuary. Marine Biodivers Rec 5: 1-5.

MAJTÁNOVÁ Z, CHOLEVA L, SYMONOVÁ R, RÁB P, KOTUSZ J AND PEKÁRIK L. 2016. Asexual Reproduction Does Not Apparently Increase the Rate of Chromosomal Evolution: Karyotype Stability in Diploid and Triploid Clonal Hybrid Fish (Cobitis, Cypriniformes, Teleostei). PLoS ONE: 11.

MAJTÁNOVÁ Z, SYMONOVÁ R, ARIAS-RODRIGUEZ L, SALLAN L AND RÁB P. 2017. "Holostei versus Halecostomi" Problem: Insight from Cytogenetics of Ancient Nonteleost Actinopterygian Fish, Bowfin Amia Calva. J Exp Zool Part B 328: 1-9.

MARCENIUK AP, CAIRES RA AND ROTUNDO MM. 2017. The icthyofauna (Teleostei) of the Rio Caeté estuary, northeast Pará, Brazil, with a species identification key from northern Brazilian coast. Pan-Amer J Aquat Sci 12: 31-79.

MARTINEZ JL, LUI RL, TRALDI JB, BLANCO DR AND MOREIRA-FILHO O. 2016. Comparative Cytogenetics of Hoplerythrinus unitaeniatus (Agassiz, 1829) (Characiformes, Erythrinidae) Species Complex from Different Brazilian Hydrographic Basins. Cytogen Gen Res 149: 191-200.
MCBRIDE RS AND HORODYSKY AZ. 2004. Mechanisms maintaining sympatric distributions of two ladyfish (Elopidae: Elops) morphs in the Gulf of Mexico and western North Atlantic Ocean. Limnol Oceanogr 49: 1173 1181.

MCBRIDE RS, MCDONALD TC, MATHESON RE, RYDENE DA AND HOOD PB. 2001. Nursery habitats for ladyfish, Elops saurus, along salinity gradients in two Florida estuaries. Fish Bullet 99: 443-458.

MCBRIDE RS, ROCHA CR, RUIZ-CARUS R AND BOWEN BW. 2010. A new species of ladyfish, of the genus Elops (Elopiformes: Elopidae), from the western Atlantic Ocean. Zootaxa 2346: 29-41.

MEDEIROS APM, XAVIER JHDA, DA SILVA MB, AIRESSOUZA L AND ROSA IMDL. 2018. Distribution patterns of the fish assemblage in the Mamanguape River Estuary, North-eastern Brazil. Mar Biol Res 14: 524-536.

MENDES AB, DUARTE MR AND SILVA EP. 2018. Biodiversity of Holocene marine fish of the southeast coast of Brazil. Biota Neotrop 18: 1-14.

MERLO MA, CROSS I, SARASQUETE C, PALAZÓNFERNÁNDEZ JL AND REBORDINOS L. 2005. Caracterización cromosómica del pez sapo Halobatrachus didactylus (Schneider. 1801) (Teleostei: Batrachoididae) mediante hibridación in situ de fluorescencia. Bolet Inst Esp Oceanogr 21: 239-246.

NIRCHIO M, FENOCCHIO AS, SWARC AAC AND PÉREZ JE. 2004. Karyology of the toadfish Porichthys plectrodon (Jordan and Gilbert, 1882) (Batrachoididae) from Margarita Island, Venezuela. Mar Biol 146: 161-165.

OBERMILLER LE AND PFEILER E. 2003. Phylogenetic relationships of elopomorph fishes inferred from mitochondrial ribosomal DNA sequences. Mol Phylogen Evol 26: 202-214.

PEREIRA CSA, ABOIM MA, RÁ P AND COLLARESPEREIRA MJ. 2014. Introgressive hybridization as a promoter of genome reshuffling in natural homoploid fish hybrids (Cyprinidae, Leuciscinae). Heredity 112: 343-350.

PINHEIRO HT, MADUREIRA JMC, JOYEUX JC AND MARTINS AS. 2015. Fish diversity of a southwestern Atlantic coastal island: aspects of distribution and conservation in a marine zoogeographical boundary. Check List 11: 1615.

RAMIREZ JL, BIRINDELLI J AND GALETTI PMJR. 2017. A New Genus of Anostomidae (Ostariophysi: Characiformes): Diversity, Phylogeny and Biogeography Based on Cytogenetic, Molecular and Morphological Data. Mol Phylogen Evol 107: 308-323.

RAY GC. 1997. Do the metapopulation dynamics of estuarine fishes influence the stability of shelf ecosystems. Bullet Mar Sci 60: 1040-1049.

SÁNCHEZ-BOTERO JI, GARCEZ DS, LEITÃO RP, TRIVÉRIO-CARDOSO V, CARVALHO PH AND 
PELLEGRINI-CARAMASCHI E. 2016. Aberturas del Cordón de Arena de La Laguna Costera Imboassica (Estado De Rio De Janeiro, Brazil) no alteran la abundancia de los peces comerciales. Bol Inst Pesca 42: 662-673.

SASAKI M, IKEUCHI T AND MAINO S. 1968. A feather pulp culture for avian chromosomes with notes on the chromosomes of the peafowl and the ostrich. Experientia 24: 923-1929.

SCZEPANSKI TS, NOLETO RB, CESTARI MM AND ARTONI RFA. 2010. Comparative study of two marine catfish (Siluriformes, Ariidae): Cytogenetic tools for determining cytotaxonomy and karyotype Evolution. Micron 41: 193-197.

SMITH DG. 1989. Order Elopiformes; Families Elopidae, Megalopidae, and Albulidae: Leptocephali. Memoir Sears
Foundation for Marine Research. In Fishes of the Western North Atlantic, Vol. 3. Sears Foundation for Marine Research, p. 961-972. New Haven, CO: Yale University.

SONG CB, NEAR TJ AND PAGE LM. 1998. Phylogenetic relations among percid fishes as inferred from mitochondrial cytochrome b DNA sequence data. Mol Phylogen Evol 10: 343-353.

TABERLET P, MEYER A AND BOUVET J. 1992. Unusually large mitochondrial variation in populations of the blue tit, Parus caeruleus. Mol Ecol 1: 27-36.

VITTURIR,CATALANOE,COLOMBAMS.,MONTAGNINO L AND PELLERITO L. 1995. Karyotype analysis of Aphanius fasciatus (Pisces: Cyprinodontiformes): AgNORs and C-band polymorphism in four populations from Sicily. Biologisches Zentralblatt 114: 392-402. 